How to cite this article:

Kadir, R., Mokhlis, S., \& Kahar, R. (2020). Child visitation rights in practice. UUM Journal of Legal Studies, 11(1), 95-115.https://doi.org/10.32890/uumjls.11.1.2020.6874

\title{
CHILD VISITATION RIGHTS IN PRACTICE
}

\author{
${ }^{1}$ Rokiah Kadir, ${ }^{2}$ Safiek Mokhlis \& ${ }^{3}$ Rojanah Kahar \\ ${ }^{1 \& 2}$ Faculty of Business, Economics and Social Development \\ Universiti Malaysia Terengganu, Malaysia \\ ${ }^{3}$ Faculty of Human Ecology, Universiti Putra Malaysia
}

${ }^{1}$ Corresponding author: rokiah@umt.edu.my

Received: 19/8/2019 Revised: 14/1/2020 Accepted: 20/1/2020 Published: 31/1/2020

\begin{abstract}
Child visitation can facilitate the continued involvement of both parents in their children's lives after a divorce. This study aims to examine the issue of visitation rights and report the results of an analysis of relevant court cases involving Malaysian Muslim families. It describes the structure or type of visitation awarded to non-custodial parents as a result of their loss of child custody. Content analysis technique was applied to elaborate on the reported court cases. A cross tabulation method was also performed to describe the frequency of cases for the respective types of visitation. This study has revealed several details about visitation rights hidden in the masses of case law. These include granted visitation rights which comprise scheduled, reasonable and dual-form visitation, counting omission of access rights which occurred most frequently including cases where parties received legal representation. The study has contributed towards a greater understanding of how visitation orders are made in practice through a quantitative analysis of past court decisions.
\end{abstract}

Keywords: Access, Act 303, child custody, scheduled visitation, reasonable visitation. 


\section{INTRODUCTION}

In custody proceedings, just as important as the issue of determining which parties are to be granted custodial orders is the need to address non-custodial parents' visitation rights. Visitation essentially is a plan of how non-custodial parents will spend time with their children. This right allows the non-custodial parents to carry out visitation and enable them to maintain close relationships with their children. The children in turn are presented with opportunities to maintain as much contact with both parents as was the case before the divorce. In addition, this visitation rights, enables both parents to jointly discharge their responsibilities for their children's upbringing and education. In arrangements involving split custody, visitation orders, can help siblings who live separately with their custodial parents strengthen family ties.

In most cases, visitation rights are expected to be granted to parents who are denied custodies. These parents are normally the fathers, since custodies are more likely to be given to mothers in the majority of custody litigations. Once given the rights, the fathers can exercise them to visit the children, and it is the mothers' duty to ensure that the fathers can do so without obstacles. Despite not being custodial parents, the fathers' responsibilities in ensuring that the children are brought up according to Islamic teachings still continue. Through the visitation rights, they can carry out their responsibilities by maintaining contact with the children in accordance with parenting plans. In some cases, custodies are granted to the fathers instead. They must then allow the mothers, who are given the visitation rights, to have access to the children for some parenting time together. In Islam, a parent should not isolate the children from the other parent in an act of malice. A hadith narrated by Al-Bukhari has provided that a person who terminates a kinship will not enter paradise $\mathrm{e}^{4}$.

Sometimes the visitation rights of the non-custodial parents are withheld by the custodial parents as a result of their inability to properly manage the high level of stress from the divorce and custody proceedings including feelings of revenge or anger. Refusal of visitation rights is sinful. This act of disregarding the psychological

\footnotetext{
Al- Bukhari, Summarized Sahih, page 952.
} 
comfort, feelings of love, and sense of attachment that children and parents may have for each other can bring about a negative impact.

Visitation rights is generally provided under section 87 of Islamic Family Law (Federal Territories) Act 1984 (Act 303). The law states that an order for custody may "(c) provide for the child to visit a parent deprived of custody ... at such times and for such periods as the Court considers reasonable, (d) give a parent deprived of custody ... the right of access to the child at such times and with such frequency as the Court considers reasonable." As can be seen, the law only provides a two-way visitation rights for the child and the non-custodial parent but does not specify the duration and frequency of the visitation. These are to be granted by the courts as they consider reasonable. The courts usually set forth the terms of visitation rights in visitation schedules; these court orders outline the specific times or circumstances under which the children may be visited. This paper describes the structures and length of visitation rights decided by the courts in past reported cases; and it identifies if there is a pattern(s) which can be drawn from the decisions on the visitation duration given to either party.

\section{HOW ARE VISITATION ARRANGEMENTS DECIDED?}

Visitation and custody are intertwined; therefore, they are often resolved together. This means that, following a divorce, the rights are usually claimed or granted in the same case as child custodies are decided. Visitation issues, together with custody matters, can be resolved through private negotiations, mediations or more formal judicial litigations. In a private negotiation, the involved parties, either the parents themselves or their lawyers, will discuss custody issues and visitation rights in an attempt to reach an agreement. There has been no empirical evidence in Malaysia on the extent of resorting to private negotiations in settling issues on custody and visitation rights; however, a study in California indicated that at least $50 \%$ of parents made decisions through private agreements (Kelly, 1994). Most of the local studies focused on the well-being of children and women after divorce (Rozumah, Rumaya, \& Rojanah, 2001; Juhari, Baharudin, Yaacob, \& Kahar, (2007); Norasyikin, 2006; Muslihah, 2010). 
If the parties cannot reach decisions privately, visitation rights can be decided through mediations (sulh). The use of mediation is mandatory before the parents can litigate the case. The law provides that it is a legal requirement that parents attempt mediation after a case is filed if the registrar is of the opinion that there is a possibility of a settlement ${ }^{5}$. Decision-making in mediation will still be made by the parents. The goal of the mediator is to help parents reach an agreement. Mediations between parents on custody and visitation matters can result in a more amicable parenting environment. Studies have indicated that non-residential parents who mediated are far more likely to maintain contact with their children (Emery, Otto, \& O'Donohue, 2005). In mediation, parents can decide on visitation details, such as the time and duration for visitation, or on more specific issues, such as place to fetch children.

A court order made allowing a parent to have custody would often include an order for visitation rights for the non-custodial parent. It may be assumed that the losing party in a custody case could have expected as much access as possible to the child; otherwise the parent would not have contested in such custody litigation. In this case, the parent can apply for a more generous amount of time and duration, such as three days a week, and if the application is granted, the parent can exercise the right to visit at the stipulated time. However, when parents live long distance from each other, the amount and frequency of visitation may depend on the needs of the child as well as what works best for the parents. A child may be asked for input on the visitation schedule in an interview with the court, after which the child's wishes on the details of visitation can be considered. The interview may be conducted with a child of mumaiyyiz age when determining the child's preference of the custodial parent.

In practice, it may occur that a parent is only interested in applying for a visitation order and does not wish to obtain custodial rights. This decision may be attributed to the occurrence of a clear indication that the child has chosen the other parent, or the belief that the former spouse can be a better parent to the child. Thus, the visitation order obtained from the court can ensure that the non-custodial parent can

(Rule 3 Shariah Court Civil Procedure [Sulh] [Federal Territories] Rules 2004). 
have access to the child in future according to the schedule agreed by the court. Court-ordered visitation following mediation or trial may promote more frequent contact because a parent with a visitation order cannot be legally prevented from seeing the child.

\section{TYPES OF VISITATION: SCHEDULED, REASONABLE AND DUAL-FORM}

Visitation time, duration, and frequency are determined by the courts, as given in section 87. In practice visitation rights can take a variety of forms. The different types of visitation rights granted by the courts include structured, reasonable and dual-form visitation. Structured or scheduled visitation may give non-custodial parents regular visitation rights based on a fixed time and specified duration. An example of scheduled visitation is a parent who is allowed to visit a child for three days a week or two days a month. Visitation rights may also be granted during school holidays, public holidays or other occasions such as Muslims' celebration of Eid.

Scheduled visitation can be suitable when there is still conflict between the parents or when the parents are not willing to cooperate with each other. Previous studies indicated that structured parenting schedule was preferred by the vast majority of parents because of its stable and known nature which reduced conflict with their children and resulted in them having better capability to plan their lives with and without the children (Kelly, 1994).

Non-structured or reasonable visitation is the order granting the right 'at reasonable times' or 'as agreed by the parties,' which leaves it to the parents to come up with a plan of parental visitation time. The order does not specify what the actual weekly or monthly visiting pattern will be.

Research has indicated that the absence of specific and detailed parenting plans can create uncertainty and conflict between the parents, and anxiety and confusion for the children about when they will next see their non-custodial parents. Issues which arise between the parents include situations where the parents with custody rights show more influence in determining the times and duration for visits. 
The custodial parent may not agree with the proposed schedule by the access parent or may consistently fail to uphold the parenting plan. The situation can get worse if the parents are not able to communicate with each other in a harmonious manner. If the days and times of visits are stated in custody orders, non-custodial parents can exercise their parental responsibilities in a more predictable manner, without power struggles or conflicts (Kelly, 1994).

Reasonable visitation may work if the parents have a good relationship. When the parents are still able to cooperate, the reasonable structure can be the preferred option as it gives both parents the discretion to work around their respective work schedules. However, reasonable visitation may cause issues between parents if disagreements or misunderstandings were to occur, and subsequently, as a result of the regularly cancelled or prevented visits, the children may suffer.

Dual-form visitation, the third alternative, comprises both scheduled and reasonable visitations. As such, the dual structure provides two options since it grants both specific and open-ended visitations. In situations where the reasonable visitation plan does not work, the non-custodial parents always have the specific order of fixed visitation to resort to, eliminating the need to go through mediation or court proceedings for a different visitation arrangement. Studies have indicated that, following divorce, many parents have moderate to high conflict in their relationship, but over time the conflict tends to weaken. Therefore within a year or two of the separation, fathers may want to avoid seeing their children if visits involved fights with the children's mothers, or mothers may try to reduce visitation to avoid hostile interactions with the fathers (King and Heard, 1999). When conflict is high, scheduled visitation can ensure that the parents have access to the children without the power struggle, and when the conflict has subsided, the parents can consider making use of reasonable visitation to allow for some flexibility in the visitation arrangements.

Dual-structure visitation can also be an option when dealing with the issue of non-exercise of visitation rights. Studies have indicated that failure to exercise visitation is a much more common factor than denial of visitation that cause the contact between absent parents and children to generally lessen over time. Non-exercise of child access 
may be attributed to certain factors, including the access parents' difficulty adjusting to their new lives and high conflict between the parents. Studies have shown that, when the visitation arrangements are flexible and regular, the non-custodial parents are more likely to exercise visitation and, when the visitation plans are rigid, they are more likely to lose contact over time (O’Connor, 2002).

\section{METHODOLOGY}

This study used content analysis technique in analyzing reported cases on child custody and visitation in Malaysia as decided under the Islamic Family Law (Federal Territories) Act 1984 (Act 303) or equivalent provisions of the State Enactments. A purposive sampling technique was applied to identify and retrieve case reports for the past thirty years between 1987 and 2017, from several databases including Current Law Journal, Lexis Nexis, and Jurnal Hukum, by using specific terms related to custody, hadhanah, visitation, etc. Selected cases in data collection comprised those decided in the specified period, which were accessible online. The researcher managed to access over 100 cases and after further screening to eliminate irrelevant cases on procedures, duplication of cases, etc., a total of forty-seven (47) cases were chosen as samples of the study.

The main objective of the study was to identify the types of visitation rights granted by the courts to the non-custodial parents. Hence, related factors such as age and gender of the children were taken into consideration in the data collection process and the trends of visitation rights were also written down in the field notes. A structured coding instrument was developed from the content analysis method to extract information from the identified cases. Systematic content analysis is characterized by a process involving a number of stages including selecting cases, coding cases and analyzing case coding, often through statistical methods. The process is preceded by the determination of a suitable research question and concluded by reporting the findings in a manner comprehensible to the legal communities (Salehijam, 2018). The use of content analysis in this manner is considered to be an appropriate method in this study as it can facilitate analysis of a larger number of cases which in turn provides a measure of broad patterns in case law (Hall, 2008). 
Visitation orders were coded under four categories: structured, reasonable, dual-form and unmentioned. Structured visitation category was coded with reference to different lengths of visitation comprising regular and special occasion-based visitation. Other items in the questionnaire included related factors such as age and gender of the children. The instrument was filled in through a perusal of the cases, and the completed instrument was used to facilitate data processing and analysis. A cross tabulation was performed to describe the frequency of cases for the respective types of visitation.

\section{ANALYSIS AND DISCUSSION}

This study is an effort to enhance our understanding of how visitation works in practice in the Malaysian context. The data collected was analyzed in accordance with the research objectives. A descriptive analysis in terms of percentage was used to explain the results. Some of the findings indicated that the typical post-divorce parenting arrangement for Muslim families in Malaysia involved custodial mothers and fathers with access. As a result of the divorce, children were more likely to be living apart from their fathers than their mothers. This study showed that mothers stood a higher chance of obtaining custodies following custody litigations (more than 60\%).

\section{Types of Visitation: Scheduled, Reasonable and Dual-form}

The findings indicated that different types of visitation rights were granted by the courts, which were structured, reasonable and dual form. Reasonable visitation comprised the highest number of cases (14 cases / 30\%), followed by structured visitation (13 cases / 28\%) and dual-form visitation ( 3 cases / 6\%). The findings also indicated that, in many of the cases, visitation rights were not mentioned at all in the custodial orders. This occurred in seventeen (17) cases (36\%). Any orders which do not spell out terms with sufficient clarity with regard to duration and time of visitation would already be difficult to implement, as illustrated in the case of Hasnan Yusof v. Yasmin Mohd $\mathrm{Yacob}^{6}$, let alone if they do not mention the rights at all. In cases where parents are absent from or are not involved in their children's lives, omission of the rights in the orders may further promote child neglect and failure to exercise visitation by the parents.

[2008] 1 CLJ (Sya) 406. 
On top of that, reasonable visitation was found to be the slightly more frequent structure than scheduled visitation awarded to noncustodial fathers, as shown in Table 1 ( 9 and 7 cases, respectively). The data indicated that more fathers may prefer contact with the children to be in a non-structured form, where the parents decide the arrangements, rather than specified by the courts. Meanwhile, the non-custodial mothers on the other hand received scheduled and reasonable visitation in an equal number of cases (4 cases, respectively). Omission of access rights was found to be more common when the non-custodial parents were the fathers rather than the mothers (11 and 5 cases, respectively). Fathers who were absent in the custody proceedings received scheduled and reasonable visitation in an equal number of cases ( 3 cases each).

Table 1: Association between Non-Custodial Parent and Visitation Type

\begin{tabular}{|c|c|c|c|c|c|}
\hline & \multicolumn{4}{|c|}{ Visitation Type } & \multirow{2}{*}{ Total } \\
\hline & Scheduled & Reasonable & Dual & No-mention & \\
\hline $\begin{array}{l}\text { Non-custodial } \\
\text { father }\end{array}$ & 7 & 9 & 2 & 11 & 29 \\
\hline $\begin{array}{l}\text { Non-custodial } \\
\text { mother }\end{array}$ & 4 & 4 & 1 & 5 & 14 \\
\hline Total & 11 & 13 & 3 & 16 & 43 \\
\hline
\end{tabular}

As shown in Table 2, reasonable visitation was somewhat more common in cases involving children of mumaiyiz age ( 7 cases), as opposed to scheduled visitation which was granted in 5 cases. Children of a younger age received scheduled visitation in a slightly higher number of cases than reasonable visitation (5 and 4 cases, respectively). Omission of visitation rights occurred more frequently in cases of children younger than the mumaiyiz age (9 and 7 cases, respectively). Children of mumaiyiz age who were interviewed for visitation preference had chosen scheduled and reasonable visitation in an equal number of cases (4 cases each). 
Table 2: Association between Age Status and Visitation Type

\begin{tabular}{|c|c|c|c|c|c|}
\hline & \multicolumn{4}{|c|}{ Visitation Type } & \multirow{2}{*}{ Total } \\
\hline & Scheduled & Reasonable & Dual & No-mention & \\
\hline $\begin{array}{l}\text { Child of mumaiyiz } \\
\text { age }\end{array}$ & 5 & 7 & 1 & 7 & 20 \\
\hline $\begin{array}{l}\text { Child of non- } \\
\text { mumaiyiz age }\end{array}$ & 5 & 4 & 2 & 9 & 20 \\
\hline Total & 10 & 11 & 3 & 16 & 40 \\
\hline
\end{tabular}

In terms of the children's gender, scheduled visitation occurred slightly more frequently than reasonable visitation for girls (7 and 5 cases, respectively). Reasonable visitation was found to be more common than scheduled visitation among boys ( 7 and 3 cases, respectively). Omission of visitation rights happened more frequently among boys than girls (10 and 5 cases, respectively).

When parties attended mediation/sulh to resolve custody disputes, scheduled visitation was ordered in two (2) cases as compared to reasonable visitation which was granted in one (1) case. A substantial difference was observed in relation to the number of cases with omission of access rights; parties who did not go through the mediation process or made any custody agreements had no visitation rights mentioned in the orders in a higher number of cases compared to parties whose cases were mediated or resolved through agreements (Tables 3 and 4).

Table 3: Association between Use of Mediation/Sulh and Visitation Type

\begin{tabular}{|c|c|c|c|c|c|}
\hline & \multicolumn{4}{|c|}{ Visitation Type } & \multirow{2}{*}{ Total } \\
\hline & Scheduled & Reasonable & Dual & No-mention & \\
\hline $\begin{array}{l}\text { Parties have gone to } \\
\text { sulh }\end{array}$ & 2 & 1 & 1 & 1 & 5 \\
\hline $\begin{array}{l}\text { Parties have not } \\
\text { gone to sulh }\end{array}$ & 10 & 9 & 2 & 16 & 37 \\
\hline Total & 12 & 10 & 3 & 17 & 42 \\
\hline
\end{tabular}


Table 4: Association between Custody Agreement and Visitation Type

\begin{tabular}{|c|c|c|c|c|c|}
\hline & \multicolumn{4}{|c|}{ Visitation Type } & \multirow{2}{*}{ Total } \\
\hline & Scheduled & Reasonable & Dual & No-mention & \\
\hline $\begin{array}{l}\text { Custody agreement } \\
\text { made }\end{array}$ & 1 & 1 & 3 & 4 & 9 \\
\hline $\begin{array}{l}\text { Custody agreement } \\
\text { not made }\end{array}$ & 9 & 11 & 4 & 10 & 34 \\
\hline Total & 10 & 12 & 7 & 14 & 43 \\
\hline
\end{tabular}

Finally, in relation to the availability of counsel representation, this study found that both spouses were represented by legal counsel in more than half of the cases (Table 5). When only one spouse was represented, the mother was more likely to be represented than the father. Excluding ex parte applications and cases of shared custody, there were 14 cases where only mothers were represented and one (1) case of a father receiving counsel service. Where representation was available to both parties, parents preferred to resolve visitation issues in terms of a scheduled rather than reasonable structure ( 8 and 5 cases, respectively). All orders of dual visitation i.e. involving both scheduled as well as reasonable structures were granted when both parents were legally represented. Reasonable visitation was preferred over scheduled visitation when only one party was represented (6 and 3 cases, respectively). Omission of visitation rights in the orders occurred even when parties were mutually represented ( 5 cases). No omission of rights was detected when only fathers received legal representation. A higher number of omissions were found when only the mothers were represented, and the fathers were not (6 cases). Generally, omission of visitation rights was slightly more common when only one party received legal representation compared to cases when both parties were mutually represented. 
Table 5: Association between Counsel Representation and Visitation Type

\begin{tabular}{|c|c|c|c|c|c|}
\hline & \multicolumn{4}{|c|}{ Visitation Type } & \multirow{2}{*}{ Total } \\
\hline & Scheduled & Reasonable & Dual & No-mention & \\
\hline $\begin{array}{l}\text { Both parents } \\
\text { represented }\end{array}$ & 8 & 5 & 3 & 5 & 21 \\
\hline $\begin{array}{l}\text { Only mothers } \\
\text { represented }\end{array}$ & 3 & 5 & 0 & 6 & 14 \\
\hline $\begin{array}{l}\text { Only fathers } \\
\text { represented }\end{array}$ & 0 & 1 & 0 & 0 & 1 \\
\hline Total & 11 & 11 & 3 & 11 & 36 \\
\hline
\end{tabular}

In relation to scheduled visitation, the most generous regular visit was 10 days a month ( 2 cases), and the most frequent regular access was fortnightly (4 cases), while the most frequent special occasion visit was part of the school holidays ( 7 cases). Other regular access included two (2) days a week, one (1) week a month, only on Sundays, and two (2) days a month visit (1 case each), and other special occasion visits were public holidays and alternate Eids (1 and 2 cases, respectively). Scheduled visitation was more common when the child involved was female and had not reached the age of mumaiyiz, and when both parties had gone through the mediation process.

In one of the cases, the court recognized that a more generous and regular visitation was required for re-establishing a long-lost relationship between a parent and his child. In Nordaliya Shamsudin v. Ahmad Nasri Shaharudin ${ }^{7}$, the defendant father sought for visitation rights and access to his ten-year-old daughter whom he had not met for some seven years. The court agreed that visitation rights on a more regular basis ought to be granted to him. The father was given the right to visit the child every Sunday from 9 a.m. to 5 p.m.

With regard to reasonable visitation, this study indicated that it was the most frequent structure granted by the courts. In 14 cases (30\%), visitation took this type of structure, where access to the child was given at reasonable times or as agreed by parties. Reasonable visitation was found to be more common when the non-custodial

7 (2010) 1 CLJ (Sya). 
parent was the father and the child involved was male and had reached the age of mumaiyiz.

The case of Hasnan Yusof v. Yasmin Mohd Yacob ${ }^{8}$ illustrates how a generally worded visitation right or a reasonable structure can give rise to problems when there is still conflict between parents, and when parents are not willing to cooperate with each other out of fear for their children's safety. In this case, the issue was whether the respondent had committed contempt of court for failing to comply with the visitation rights. The case involved an application under section 229 of the Shariah Court Civil Procedure (Federal Territories) Act 1998 for an order of committal against the respondent on the grounds that the respondent had committed contempt of court when she did not comply with the terms relating to the visitation rights granted to the applicant. The custody order had given the applicant a visitation right for two days a week. The applicant was not happy as every time he wished to visit the child, the respondent only allowed him to see the child from outside a grilled gate, restricting him from having a good time with the child. In response, the respondent argued that she did not commit any contempt of court as there was no specification in relation to the manner the visitation right could be exercised as stated in the custody order. The respondent also explained that the restrictions imposed in access was a necessary protective action given that the applicant had once absconded with the child for six months, and only returned the child after she had obtained an ex parte custody order and after a warrant of arrest had been issued against the applicant. The court viewed the act of the respondent in providing restricted access to the applicant as undesirable but was consistent with the term 'as circumstances permitted' as stated in the order. Having accepted the justification for the imposition of limitations to the visits, the court dismissed the application for committal order. The court admitted that the dispute was attributed to the generally worded court order, and to remedy the problem, a new and more specific visitation rights had to be issued with detailed terms attached, allowing the child to be visited within specified days. The previous custody order allowing the father a visit of two days a week was already specific as far as the time plan was concerned, but the lack of a good relationship between the parents did not only require the duration of the visit to [2008] 1 CLJ (Sya) 406. 
be spelt out but also the method of the visit to be made clear. The new order requiring the removal of any physical restriction, such as a grilled gate, and the visitation to take place under the supervision of another individual to be identified by the respondent has resulted in a more satisfactory visitation right. This has enabled the applicant to maintain unrestricted contact with the child whilst the mother's concerns about the child's safety has equally been given due consideration through the supervision requirement.

Finally, in relation to the dual forms of visitation, this type took place only in three cases (6\%). Access was given at reasonable times with part of school holidays (two cases) and reasonable time plus two days a month (one case). Two of the cases involved children of a younger age.

\section{Does Increased Access Serve Children's Interests Better?}

One way to address the emotional support and well-being of children is through frequent and continuous contact with the absent parents. Visits by the non-resident parents are crucial for the children's mental, social, intellectual and character development and well-being. Previous studies have indicated that there is a positive association between the social and the economic involvement of non-resident fathers in their children's lives (Zaleha, Roziana, \& Noorfaizah, 2005; Juhari et.al., 2007). Greater contact between children and fathers is associated with higher child support compliance, payment of more supplemental child expenses, and less father dropout in the longer term. Some studies also suggested that father-child contact has beneficial effects on children. Contact promotes higher psychological scores, greater self-esteem, fewer behavioural problems, higher academic achievement, and better peer relationships Loss of contact with their absent parent is described by children as the aspect of their parents' divorce that is most upsetting (Manning \& Smock, 1999). Social interactions with non-resident fathers have been correlated with a wide range of positive results including fewer behavioral and emotional problems (Garasky, Stewart, Gundersen, \& Lohman 2010).

Fathers who visit their children every week are likely to establish more secure relationships than fathers who rarely visit. Can in-person 
meetings with non-resident parents be replaced with electronic communication? Studies have shown that the availability of telephone and electronic mail communication makes no difference for parents who do not maintain physical meetings with their children. Fathers who have little or no in-person contact rarely compensate in other ways of communication such as by phone or mail. However, for existing good relationships between parents and children, the use of electronic communication can enhance them. Studies found that fathers who visited regularly, communicated most often in other ways as well (King et. al, 1999).

In early studies of children in maternal custody, few contacts with their fathers were described as being the cause of the children's intense dissatisfaction. The children in mother-custody homes were dissatisfied with the twice monthly weekend visitation (i.e. two days a month) and were sad or depressed with the diminished presence or the loss of their fathers from their lives. The issue can be addressed by increased access through the addition of a weekly overnight. The number of days where children wait between visits should be shortened and the amount of time spent with the parents should be increased from less than $15 \%$ to nearly $30 \%$ on a monthly basis (Kelly, 1994). These studies could indicate that increased access to the non-residential father after divorce is needed by the children.

Studies found a strong connection between written plans of visitation and the actual occurrence of parental visits (Kovalesky, 2001). A higher frequency of visits stipulated in the agreements or court orders would correspond to a higher number of visits taking place. In the light of these findings, ensuring that fathers have a generous visitation schedule is important. It would encourage more frequent actual visits and hence promote a closer emotional bond with the children. With more frequent visitation taking place, the likelihood of maintaining financial support for the children is also increased.

\section{Denial of Visitation and Failure to Exercise Visitation}

Issues concerning visitation include unwarranted access denial and failure to exercise access. Is non-violation guaranteed with the issuance of visitation orders or agreements? The answer is likely to be in the negative. Denial of access would still happen despite 
the visitation order as a result of lack of tolerance, malice against the non-custodial parents, the fear that the non-custodial parents would abscond with the children, or an insistence to maintain status quo living arrangements as parents (Noor, 2014). Denial of access, according to some custodial parents, is attributed to the fear of the possibility that the children would be kidnapped, inadequately cared for physically, or sexually abused. It is also attributed to the fear of the non-resident parent's immoral behaviour, such as alcohol or drug abuse (O’Connor, 2002).

The most common form of denial of access occurs when the custodial parent consistently refuses to allow the other parent to visit the children. As a result of the denial, the children's welfare is clearly disregarded as they are deprived of a relationship with the non-custodial parent. Denial of access by one parent against another was illustrated in the case of Norsuhaila Eliani bt Suhaimi v. Jimmy Shanley bin Norjahan Saleh ${ }^{9}$. The court ordered that the father be given the right to stay overnight with the child for three days a week. The mother defaulted on the order, prompting the father to file an application for enforcement of committal order against the mother. The Shariah High Court allowed the application for committal and ordered the mother to be imprisoned for seven days. The mother appealed, but the court dismissed the appeal, finding that the committal order should be retained to give awareness that any order of court should be obeyed. The sentence was reduced to three days as the father was once allowed to stay overnight with the child.

Access may be the main problem or one of the issues that causes ongoing hostility between parents after divorce. Disputes concerning access may stem from another problem, such as the failure of the non-resident father to pay for child support. The issue of access is more likely to occur in cases when there is high conflict among the parents, and when the conflict is not resolved within the first year of the divorce (O'Connor, 2002).

One way to reduce potential problems concerning access denial is through structured visitation rights. By outlining in a specific and clearer form when visitation will occur, structured visitation can

9 (2017) 2 ShLR. 
facilitate compliance, and in the event of a violation of rights, denial of access can be proven with relative ease if the offending parent is to be charged for committal proceedings. In this way, it may have some deterrent effects that could discourage potential violations from taking place. Violations involving serious issues such as when the custodial parent consistently refuses to allow the other parent to visit the child may necessitate recourse to court intervention. Denial of access can result in an application of committal proceedings being filed against the refusing parent. Denying access can have serious consequences for the children as well. A study in Canada indicated that denied access can lead to situations where fathers would no longer be seeing and cease having contact with the children (O’Connor, 2002).

Another problem concerning visitation is the failure of the noncustodial parents to exercise visitation obligations. Studies indicated that such parental contact with the children tends to generally diminish over time. However, fathers who pay child support are much more likely to maintain contact with their children and visit them more frequently than those who do not. Failure to exercise access is more common than access denial. Non-exercise of child access may be attributed to access denial, high conflict between the parents, the access parents' difficulty adjusting to their new lives, and socio-economic factors. Whether visitation rights are exercised or not is also influenced by the state of relationship between the parents. The better the relationship between them, the more likely the absent parent is to exercise visitation obligations (O'Connor, 2002).

An allegation of denial of visitation by a parent may be countered as a case of failure to exercise visitation by another parent. The case of Roslaili bt Abdul Ghani v. Ahmad Azman bin Yaacob ${ }^{10}$ illustrates this point. The order stated that the defendant father must give the children to the plaintiff mother from 6 p.m. every Friday to 6 p.m. every Sunday. The defendant failed to abide by the order, causing the plaintiff to commence the application to commit the defendant to prison. The defendant denied the allegation by the plaintiff, arguing that the plaintiff merely visited his house, where she was given the

10 (2006) 1 ShLR. 
opportunity to take the children. The plaintiff however had failed to take the children, as they declined to go with the plaintiff who came accompanied by her new husband with whom the children were not familiar. The court attempted to resolve the dispute by seeking guidance from the detailed terms in the order, and since the order was not clear in relation to where and how to fetch the children, the court dismissed the plaintiff's application, noting that the plaintiff should have applied for the order to be amended.

There has been limited research in Malaysia on the extent of nonresident parents exercising visitation rights following custody litigations. Cases where parents do not participate in custody proceedings may indicate that they have little interest in their children and visitation rights if granted may not be duly exercised by the parents. The likelihood of failure to exercise visitation rights is illustrated in the case of Sabrina bt Kamarudin v. Mohd Syawal bin Sulaini ${ }^{11}$. Since their divorce, the child had lived with the maternal grandparent, and the father did not file a statement of defense, nor was he present during custody proceedings. The father never visited the child while he was under the care of the grandparent. The father was granted a two-hour visit for three days per week with custody given to the mother. It may well be argued that the granting of the access right would in no way guarantee that visitation would take place, and it is more than likely that the parent may not exercise the access right given his previous conduct and relationship with the child. However, the inclusion of the access rights in the order is commendable based on a study conducted by Kovalesky (2001), which showed that written plans of visitation can generally promote actual occurrence of parental visits. More importantly, visitation is not only a matter of parental rights, but the rights of the child as well. Section 87 (c) and (d) contains a two-way right, the right for the child to visit the parent as well as the right for the parent deprived of custody to visit the child.

\section{CONCLUSION}

Child access can facilitate continued involvement of both parents in their children's lives after divorce. The importance of visitation can

11 (2013) 4 ShL. 
never be overstated, as previous studies have established association between access and children's positive well-being. The amount of access is also important, greater access is warranted for better wellbeing of the children. The frequency and length of the visits may become important if the objective of the guiding policy is to promote children's welfare and best interests.

This study provides an overview of how child access has been decided in the past 30 years involving Muslim families in Malaysia. The paper identifies possible structures that may explain visitation rights and provides insights on how visitation orders are made in practice based on past court decisions. The pattern of visitation decisions indicated that visitation rights comprised three forms: scheduled, reasonable and joint structures. The most common was reasonable visitation followed by the scheduled structure. The 'no visitation order' occurred most frequently in reported cases. Reasonable and structured contacts were given in close to twothirds of the cases. In the context of scheduled access, the access allowed was regular access and special occasion visitation such as Eid and school holidays in nearly one-third of the cases. The absent parents were given visitation rights with varied frequency. The most common visitation granted to non-custodial parents was fortnightly or alternate weekend visitation. Non-custodial fathers were more likely to be granted reasonable visitation, and children of younger ages were more likely to receive structured visitation by the noncustodial parents.

The analysis attempted in this paper was exploratory and therefore may have its constraints, given the limited number of reported cases which may not represent all actual cases decided by the courts. Future studies in Malaysia could take advantage of all cases, including unreported ones, as a richer data would help in deliberating on the generosity issue of visitation rights including its potential association with related variables. Socio-legal research may also be undertaken to understand what demographically different non-custodial parents prefer in relation to the structures and length of visitation rights. It is vital to ensure that non-custodial parents assume their responsibilities for the children in terms of general upbringing, education, discipline, and future career even though the children are living with the other parents. 


\section{ACKOWLEDGEMENTS}

This research received no specific grant from any funding agency in the public, commercial, or not-for profit sectors.

\section{REFERENCES}

Che Soh, R. (2014). Children's participation in custody and access proceedings. IIUM Law Journal, 22(1), 53-73.

Emery, R. E., Otto, R. K., \& O’Donohue, W. T. (2005). A critical assessment of child custody evaluations: Limited science and a flawed system. Psychological Science in the Public Interest, 6(1), 1-29.

Garasky, S., Stewart, S. D., Gundersen, C., \& Lohman, B. J. (2010). Toward a fuller understanding of non-resident father involvement: An examination of child support, in-kind support, and visitation. Population Research and Policy Review, 29(3), 363-393.

Hall, M. A., \& Ronald, F. (2008). Systematic content analysis of judicial opinions. California Law Review, 96(1), 63-122.

Juhari, R., Baharudin, R., Yaacob, S. N., \& Kahar, R. (2007). Divorce Families in Malaysia, Children and Adults Wellbeing: IRPA Report. UPM: Faculty of Human Ecology.

Kelly, J. B. (1994). The determination of child custody. The Future of Children, 4(1), 121-142.

King, V., \& Heard, H. E. (1999). Nonresident father visitation, parental conflict, and mother's satisfaction: What's best for child well-being. Journal of Marriage and Family, 61(2), 385-396.

Kovalesky, A. (2001). Factors affecting mother-child visiting identified by women with histories of substance abuse and child custody loss. Child Welfare, LXXX(6), 749-768.

Manning, W. D., \& Smock, P. J. (1999). New families and nonresident father-child visitation. SocialForces, 78(1), 87-116.

Mohd Zin, N., Abdul Hak, N., Mohd, A., Abd Malek, N., Ibrahim, N., Che Soh, R. ... Ibrahim, B. (2016). Islamic Family Law in Malaysia. Kuala Lumpur, Malaysia: Thomson Reuters Malaysia Sdn. Bhd.

Muslihah, H. (2010). Knowledge and accessibility of Muslim women to the law on post-divorce financial support. IIUM Law Journal, 18(1), 123-142. 
Muslihah, H. (2009). Relationships between satisfaction of Muslim women on financial supports after divorce and ex-husbands' compliance to the supports with post-divorce welfare. Pertanika Journal of Social Science and Humanities, 17(2), 153-166.

Noor, Z. (2014). Access denial: Reference to the cases decided in the Shariah Court in Malaysia. Shariah Journal, 22(2), 129-160.

Nor 'Asyikin, H. (2006). A Socio-legal perspective on the impact of divorce on children's welfare: Apilot study on children living with single mothers in selected rural areas in Selangor. (Unpublished masters dissertation in Comparison Law). International Islamic University Malaysia, Kuala Lumpur.

O'Connor, P. (2002). Child access in Canada: Legal approaches and program supports. Department of Justice Canada. Retrieved from https://www.justice.gc.ca/eng/rp-pr/fl-lf/famil/2002_6/ pdf/2002_6.pdf

Rozumah, B., Rumaya, J., \& Rojanah, K. (2001). Predictors of the wellbeing of children from non- traditional families. Human Ecology Research Bulletin, 2(1), 16-22.

Salehijam, M. (2018). The value of systematic content analysis in legal research. Tilburg Law Review, 23(1), 34-42.

Zaleha, K., Roziana, M. A., \& Noorfaizah, A. (2005). A preliminary study on non-custodial father's contact with their children after divorce in Malaysia. IKIM Law Journal, 9(1), 177-200. 